Crop Breeding and Applied Biotechnology 5:142-148, 2005

Brazilian Society of Plant Breeding. Printed in Brazil

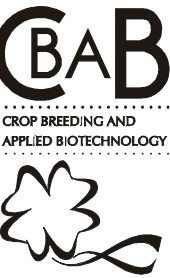

\title{
Genetic gain in an improvement program of irrigated rice in Minas Gerais
}

Plínio César Soares ${ }^{1 *}$, Patrícia Guimarães Santos $\mathrm{Melo}^{2}$, Leonardo Cunha Melo ${ }^{3}$, and Antônio Alves Soares ${ }^{4}$

Received 11 November 2004

Accepted 11 March 2005

\begin{abstract}
An evaluation of the genetic improvement program of irrigated rice of Minas Gerais estimated the genetic gain obtained in the 90s. Grain yield data of the advanced comparative trials of cultivars and lines of continuously flooded rice, conducted from 1990/91 to 2000/01 were used. The estimate of the genetic gain was obtained by the methodology of the adjusted means proposed by Breseghello (1998). The mean annual genetic gain in the $90 \mathrm{~s}$ was $42.45 \pm 17.89 \mathrm{~kg}$ ha-1 (0.7\% per year). The improvement program proved auspicious for the development of lines that outmatched the controls. The mean of the cultivars released in the 90s did however not outstrip the mean of the elite lines, which were the genotypes with the highest means in this study and will be further evaluated in the ongoing program.
\end{abstract}

Key words: Oryza sativa, genetic improvement, cultivars.

\section{INTRODUCTION}

The establishment of estimates of the genetic progress is highly important in plant improvement; they allow the evaluation of the efficiency of a program in the development of new lines and more precise new strategies that guarantee the breeder's success at conducting segregating populations and establish new cultivars. The genetic gains for grain yield are the longer the smaller - a fact that might be related to the parents used or the focus set on other traits than grain yield.

In the final phase of an improvement program, the new cultivars are tested rigorously and in-depth for over at least two years in the main producing regions before the recommendation or release. Every year, new lines are introduced in the trials for an evaluation in various sites, eliminating those with a low yield potential. The evaluation of the performance of the program over the years is therefore important for the direction of future studies on genetic improvement aiming at yield increase, good grain quality and disease resistance.

In many cases the improvement programs of various economically important crops have been evaluated by estimates of the genetic gain. Rangel et al. (2000) estimated

${ }^{1}$ Empresa de Pesquisa Agropecuária de Minas Gerais, C. P. 216, 36.570-000, Viçosa, MG, Brasil. *E-mail: plinio@epamig.ufv.br

${ }^{2}$ Setor de Melhoramento de plantas, Escola de Agronomia e Engenharia de Alimentos, Universidade Federal de Goiás, C. P. 131, 74.001-970, Goiânia, GO, Brasil ${ }^{3}$ Embrapa Arroz e Feijão, C. P. 179, 75.375-000, Santo Antônio de Goiás, GO, Brasil

${ }^{4}$ Departamento de Agricultura, Universidade Federal de Lavras, C. P. 37, 37.200-000, Lavras, MG, Brasil 
a gain of $0.3 \%$ per annum from $1984 / 85$ to $1996 / 97$ for the yield of irrigated rice in the north region of Brazil. Santos et al. (1999) evaluated the genetic gain of the improvement program of irrigated rice in Minas Gerais from 1974/75 to 1995/96; results showed increases in the cultivars' yield potential in the first five years only. For the same crop, Breseghello et al. (1999) estimated a mean gain of $0.8 \%$ per year in the improvement program of irrigated rice of Embrapa Arroz and Feijão in the Northeast of Brazil. Abreu et al. (1994) estimated a gain of $1.9 \%$ in the new bean genotypes, compared with the most planted cultivar, the Carioca. Carvalho et al. (1997) evaluated the improvement program of the herbaceous cotton plant of the Northeast and estimated a gain in cotton seed yield of $1.03 \%$ per year between 1976 and 1994. Other recent study on cotton, Machado et al. (2003) observed gains for cotton seed yield of around $3.5 \%$. The annual genetic gain observed by Vencovsky et al. (1986) for maize over 20 years was $2.2 \%$ for populations and of $1.7 \%$ for commercial hybrids.

Fernandes and Franzon (1997) also estimated the genetic gain of maize in 30 years (1963 to 1993) in Brazil. They compared the methodology of Vencovsky et al. (1986) with a modification of this methodology. In the first case, the estimate of the genetic gain was $1798 \mathrm{~kg} \mathrm{ha}^{-1}$, in the second the estimated value was more than twice the first (3.96 kg ha-1). The authors considered the latter more accurate as it reflected the classic concepts of genetic gain better. This methodology did not include the mean of common genotypes in two consecutive years in the estimate of the genetic gain, while the traditional methodology considered these means and produced underrated values.

Several methodologies can be used to obtain the genetic gain, among which we cite the frequently used methodology proposed by Breseghello (1998) (adjusted means) for rice and cotton (Santos et al. 1999, Machado et al. 2003). Breseghello et al. (1998) compared three methodologies: Vencovsky, controls and adjusted means to estimate the genetic gain of the improvement program of irrigated rice in the Northeast. The author concluded that the methodology of the adjusted means proved more versatile to obtain estimates of genetic gain based on trial data series, besides dismissing standard controls and allowing the use of unbalanced data.

The methodology of adjusted means was used in the present study to estimate the genetic gain achieved in the improvement program of continuously flooded rice developed in Minas Gerais by the study group of the Empresa of Pesquisa Agropecuária of Minas Gerais (EPAMIG) and EMBRAPA Arroz and Feijão between 1990/91 and 2000/01.

\section{MATERIAL AND METHODS}

The estimate of the genetic gain was obtained based on grain yield data of the advanced comparative trials with cultivars and lines of continuously flooded rice, conducted in Minas Gerais from 1990/91 to 2000/01. During the program, any group of cultivars and/or lines that did not perform well was discarded and substituted by others.

The number of trials per crop year varied from three to six, amounting to 48 trials that were arranged in a random block design with four replications. The number of treatments per trial varied from 20 to 25 , including the control cultivars. The data were the means of grain yield of the lines and cultivars evaluated in each year. These means were repeated $\mathrm{k}$ times for each line/cultivar, where $\mathrm{K}$ was the number of replications of the trials multiplied by the number of sites in each year. The analysis of variance was realized using the GLM (generalized linear model) procedure of the program SAS Institute Inc. (1985), which provides the matrix $\left(\mathrm{X}^{\prime} \mathrm{X}\right)^{-1}$ and vector of $\mathrm{e}^{\circ}$ solutions.

The vector of means of the lines/cultivars adjusted to the effect of year, product of the analysis, was obtained by: $\mathrm{Y}=\mathrm{A} \theta^{\circ}$

$\tilde{\hat{\mathrm{Y}}}$ : vector of line/cultivar means adjusted to the year

A : matrix of coefficients with the dimensions $n_{k} \times\left(1+a+n_{k}\right)$ $\theta_{\sim}^{\circ}$ : vector of solutions provided by the GLM

$\mathrm{n}_{\mathrm{k}}$ : number of lines/cultivars evaluated in the year $\mathrm{k}$, and a: number of years.

The matrix of covariance of the line/cultivar means adjusted to the year effect was obtained by:

$\hat{\mathrm{V}}(\hat{\mathrm{Y}})=\mathrm{A} \hat{\mathrm{V}}(\theta) \mathrm{A}^{\prime}$ where

$\hat{V}(\theta)$ : estimator of the matrix of covariance of the parameters given by:

$\hat{\mathrm{V}}(\theta)=\left(\mathrm{X}^{\prime} \mathrm{X}\right)^{-} \mathrm{MS}_{\mathrm{GA}}$ where

$\left(X^{\prime} X\right)^{-}$: generalized inverse value of the matrix $X^{\prime} X$, provided by the GLM procedure of SAS

$\mathrm{MS}_{\mathrm{GA}}$ : Mean square of the interaction lines/cultivars and years.

The methodology of the adjusted means proposed by Breseghello (1998) was used to obtain the estimate of the genetic gain. Using the vector of adjusted means $(\hat{\mathrm{Y}})$, the means of the groups of lines/cultivars that constituted the trials of each year were obtained, considering all available observations in the evaluation period by:

$\mathrm{Y}^{*}=\mathrm{S} \mathrm{Y}$, where

$\tilde{\mathrm{S}}$ : auxiliary matrix with dimension a $\mathrm{n}$, where each line refers to year $\mathrm{j}$ and each column to line/cultivar $\mathrm{i}$. If line/ cultivar i participates in year $\mathrm{j}$, the cell $\mathrm{ji}$ is filled in with the 
inverse value of the number of lines/cultivars tested in year $\mathrm{j}$; if it does not participate, the value of the cell is zero.

The matrix of covariance of the means of the groups of lines/cultivars was obtained by the equation:

$\hat{\mathrm{V}}\left(\hat{\sim}^{*}\right)=\mathrm{S} \mathrm{V}(\underset{\sim}{\mathrm{Y}}) \mathrm{S}^{\prime}$

In the following, the vector of gains observed (Gobs) between two consecutive groups was estimated and the matrix of covariance between these same gains, $\hat{\mathrm{V}}(\mathrm{Gobs})$, respectively, by:

$$
\underset{\sim}{\mathrm{Gobs}}=\mathrm{C}_{\sim^{\mathrm{Y}}}^{*} \quad \text { and } \quad \hat{\mathrm{V}}(\underset{\sim}{\mathrm{G} o b s})=\mathrm{C} \hat{\mathrm{V}}\left(\hat{\sim}_{\hat{\mathrm{Y}}}^{*}\right) \mathrm{C}^{\prime}
$$

where $\mathrm{C}$ is a matrix with -1 in the principal diagonal and 1 in the first superior diagonal, and the remaining containing zero.

Having established Gobs and $\hat{V}(\mathrm{Gobs})$, the mean annual genetic gain $\left(\mathrm{G}_{\mathrm{m}}\right)$ was estimated by the generalized least square method:

$$
\mathrm{Gm}=\left(\mathrm{X}^{\prime} \hat{\mathrm{V}}_{\text {Gobs }}^{-1} \mathrm{X}\right)^{-1} \mathrm{X}^{\prime} \hat{\mathrm{V}}_{\text {Gobs }}^{-1} \text { Gobs }
$$

where $\mathrm{X}$ is a vector column of $1 \mathrm{~s}$. It can be demonstrated that $\left(\mathrm{x}^{\prime} \mathrm{v}_{\mathrm{Gobs}}^{-1} \mathrm{x}\right)^{-1}$ is an estimator of the variance of GM.

The rate of genotypic substitution was obtained using software Genes (Cruz 2001) in the following proportions:

$$
\begin{array}{ll}
\% \mathrm{I}=\frac{100 \mathrm{I}}{\mathrm{M}+\mathrm{E}+\mathrm{I}} & \% \mathrm{M}=\frac{100 \mathrm{M}}{\mathrm{M}+\mathrm{E}+\mathrm{I}} \\
\% \mathrm{E}=\frac{100 \mathrm{E}}{\mathrm{M}+\mathrm{E}+\mathrm{I}} & \% \mathrm{R}=\frac{100 \mathrm{I}}{\mathrm{M}+\mathrm{I}}
\end{array}
$$

where:

$\% \mathrm{I}$ : percentage of new lines/cultivars in relation to the previous year

$\% \mathrm{M}$ : percentage of lines/cultivars maintained for evaluation in the following year

$\% \mathrm{E}$ : percentage of lines/cultivars excluded from the evaluation in the following year

$\%$ R: percentage of renewal of lines; being

M: number of lines/cultivars passed on from one year to the other. In relation to years 1 and $2, M=n_{12}$

$\mathrm{E}$ : number of lines/cultivars excluded from one year to the other. In relation to years 1 and $2, E=n_{11}-n_{12}$

I: number of lines/cultivars included in the subsequent year. in relation to years 1 and $2, \mathrm{I}=\mathrm{n}_{22}-\mathrm{n}_{12}$ $\mathrm{n}_{11}$ : number of lines/cultivars evaluated in year 1

$\mathrm{n}_{22}$ : number of lines/cultivars evaluated in year 2 .

\section{RESULTS AND DISCUSSION}

The joint analysis of variance showed highly significant differences $(\mathrm{P}<0.01)$ between the lines/ cultivars, indicating the existing genetic variability for this trait. This allows for the selection of lines with a better performance that meet the program's demands. The means of grain yield adjusted to the effect of year for all cultivars and lines are shown in Table 1; the amplitude of variation of the grain yield was between 3348 and $6986 \mathrm{~kg} \mathrm{ha}^{-1}$.

Table 2 presents the estimates of the annual and accumulated genetic gain in relation to the mean of the lines/cultivars in the first year and the mean genetic gain in the entire period. The annual genetic gain oscillated from 858.10 to $-648.5 \mathrm{~kg} \mathrm{ha}^{-1}$, presenting a large amplitude of variation. The negative gains showed that there was loss with the substitution of the discarded genotypes, probably because other traits than yield were considered during the process of elimination and introduction of new lines. The highest gain in the period was in 1993/94, owing to the introduction of productive lines such as IAC 1289, CNA 7809 and CNA 7857, the latter released under the name Rio Grande in 1999. Main advantages of this genotype were the resistance to the main fungal rice diseases (leaf blast, brown spot and grain staining), besides excellent culinary traits with lose and soft grains after cooking.

There was a significant reduction in the two consecutive years (1994/95 and 1995/96), accumulating an annual genetic gain of $-612.40 \mathrm{~kg} \mathrm{ha}^{-1}$, the most expressive of the entire period. After this phase, the reduction in the gain was smaller, resulting in a slight but significant increase in the two following years.

The mean annual genetic gain in the 90 s was $42.45 \pm$ $17.89 \mathrm{~kg} \mathrm{ha}^{-1}$ (a mean gain of $0.7 \%$ year) significant at $5 \%$ by the $t$ test. This corresponds to an inferior increment of the annual mean irrigated rice yield compared to the values obtained by Soares and Ramalho (1993) for irrigated rice in Minas Gerais in the 80 s (1.6\% year); and by Santos et al. (1999). These authors evaluated the performance of this improvement program in Minas Gerais in the 70s (1974/ 75 to $1979 / 80$ ) and obtained a highly significant gain of $203 \mathrm{~kg} \mathrm{ha}^{-1}$ year $^{-1}(6.06 \%)$.

Analyzing the beginning of the program of irrigated rice in the state of Minas Gerais in the 70s, one notes that countless cultivars of the traditional group participated in the trials, and that after their substitution by improved lines/cultivars during the two following decades, smaller or nearly no gains at all were obtained (Santos et al. 1999). In the last years, the program also focused on the selection of other traits of interest such as grain quality and disease 
Table 1. Grain yield means adjusted to the year effect of the cultivars and lines of irrigated rice evaluated in Minas Gerais from 1990/ 91 to $2000 / 01$

\begin{tabular}{|c|c|c|c|c|c|}
\hline Cultivars/lines & $\begin{array}{c}\text { Grain yield } \\
\mathrm{kg} \mathrm{ha}^{-1}\end{array}$ & Cultivars/lines & $\begin{array}{c}\text { Grain yield } \\
\mathrm{kg} \mathrm{ha}^{-1}\end{array}$ & Cultivars/lines & $\begin{array}{c}\text { Grain yield } \\
\mathrm{kg} \mathrm{ha}^{-1}\end{array}$ \\
\hline SC 141 & 6986 & BRIMS 2 & 6066 & IAC 101 & 5634 \\
\hline CNA 8879 & 6805 & CNA 8885 & 6061 & MG 445 & 5632 \\
\hline CNA 8575 & 6641 & CNA 7809 & 6041 & CNA 6727 & 5620 \\
\hline PR 501 & 6627 & CNA 8621 & 6020 & MG 447-Mucuri * & 5602 \\
\hline CNA 8731 & 6625 & CNA 8369 & 6010 & EPAGRI 97-05 & 5554 \\
\hline PR 498 & 6571 & CNA 8622 & 6007 & MG 470 & 5532 \\
\hline CNA 8479 & 6535 & CNA 8875 & 5963 & BR-IRGA $409 * *$ & 5525 \\
\hline RIO FORMOSO* & 6525 & CNA 8485 & 5960 & Embrapa 7 Taim ** & 5518 \\
\hline CNA 7553 & 6510 & PR 67 & 5946 & MG $2 * *$ & 5476 \\
\hline CNA 7550 & 6477 & CNA 8859 & 5933 & IRGA $97-28$ & 5430 \\
\hline CNA 7857-Rio Grande * & 6468 & CNA 6771 & 5919 & IAC 100 & 5396 \\
\hline CNA 8450 & 6450 & PR 306 & 5907 & CNA 6804 & 5396 \\
\hline SC 138 & 6426 & CNA 6088 & 5898 & CNA 8618 & 5372 \\
\hline CNA7556-Ouro Minas * & 6406 & CNA 8883 & 5896 & CNA 8033 & 5368 \\
\hline IAC 1289 & 6392 & ALIANÇA** & 5893 & CNA 8245 & 5334 \\
\hline METICA $1 * *$ & 6371 & PR 631 & 5878 & PR 380 & 5325 \\
\hline CNA 8728 & 6356 & URUCUIA * & 5861 & CNA 8760 & 5282 \\
\hline CNA 8872 & 6346 & CNA 4898 & 5857 & CNA 8244 & 5257 \\
\hline CNA 8573 & 6338 & EPAGRI 109 & 5848 & MG 476 & 5206 \\
\hline SC 158 & 6336 & CNA 8919 & 5844 & IRGA 97-05 & 5121 \\
\hline CNA 8730 & 6314 & CNA 8624 & 5844 & CNA 8242 & 4995 \\
\hline CNA 8874 & 6274 & MG 475 & 5809 & IRGA 97-11 & 4975 \\
\hline CNA 7204 & 6267 & $\mathrm{SC} 2$ & 5808 & IRGA $97-10$ & 4957 \\
\hline CNA 8732 & 6255 & CNA 8625 & 5795 & CNA 7967 & 4932 \\
\hline CNA 8616 & 6237 & CNA 6808-Jequitibá * & 5784 & EPAGRI 97-06 & 4921 \\
\hline CNA 8868 & 6188 & CNA 8294 & 5776 & CNA 7151 & 4911 \\
\hline CNA 8454 & 6187 & IAPAR 58 & 5747 & MG $1 * *$ & 4850 \\
\hline CNA 7940 & 6175 & CAPIVARI * & 5734 & CNA 8262 & 4842 \\
\hline EPAGRI 97-01 & 6141 & CNA 6343 & 5732 & CNA 8277 & 4711 \\
\hline CNA 8041 & 6130 & CNA 8881 & 5710 & CNA 7941 & 4693 \\
\hline CNA 8722 & 6108 & INCA $* *$ & 5707 & CNA 8263 & 4680 \\
\hline CNA 8496 & 6101 & CNA 8619 & 5690 & CNA 7971 & 4660 \\
\hline CICA $8 * *$ & 6101 & CNA 6091 & 5665 & CNA 8003 & 4220 \\
\hline PR 349 & 6084 & CNA 8857 & 5654 & CNA 7552 & 3348 \\
\hline CNA 8626 & 6076 & SAPUCAI * & 5654 & Mean & 5789 \\
\hline
\end{tabular}

* Cultivars released in Minas Gerais from 1990/91 to 2000/01

** Cultivar controls

resistance. This shows that the concern of the researchers, besides boosting the grain yield, should go in direction of meeting the demands of consumers, industries and rice farmers, aiming at cost reduction and selecting diseaseresistant lines/cultivars of greater productive potential and an enhanced grain quality.
In spite of the small genetic gain achieved by the improvement program of irrigated rice of Minas Gerais in the last decade, it proved effective for the release of cultivars, making seven lowland rice cultivars available for farmers. Among these, the most planted actually in the state are: Urucuia, Jequitibá, Rio Grande and Ourominas, 
PC Soares et al.

Table 2. Estimates of the adjusted means of the lines/cultivars of irrigated rice, annual genetic gain and accumulated annual genetic gain in pairs of years

\begin{tabular}{|c|c|c|c|c|}
\hline Years & $\begin{array}{l}\text { Adjusted means of } \\
\text { line/cultivar groups }\end{array}$ & $\begin{array}{c}\text { Annual genetic gain } \\
\qquad \mathrm{kg} \mathrm{ha}^{-1}\end{array}$ & Gain Standard error ${ }^{1}$ & $\begin{array}{l}\text { Accumulated annual } \\
\text { genetic gain } \mathrm{kg} \mathrm{ha}^{-1}\end{array}$ \\
\hline $1990 / 91 / 92$ & 5860.92 & & & \\
\hline $1992 / 93$ & 5495.03 & -185.89 & -2.90545 & -185.89 \\
\hline $1993 / 94$ & 6353.14 & 858.10 & 11.03023 & 672.21 \\
\hline $1994 / 95$ & 5717.02 & -636.11 & -7.65434 & 36.10 \\
\hline $1995 / 96$ & 5068.53 & -648.50 & -11.1936 & -612.40 \\
\hline $1996 / 97$ & 5542.69 & 474.16 & 6.638974 & -138.23 \\
\hline $1997 / 98$ & 5783.57 & 240.88 & 3.35924 & 102.65 \\
\hline $1998 / 99$ & 5823.10 & 39.53 & 0.41563 & 142.18 \\
\hline $1999 / 00$ & 5613.21 & -209.89 & -1.43822 & -67.71 \\
\hline $2000 / 01$ & 5898.93 & 285.71 & 1.895783 & 218.01 \\
\hline \multicolumn{2}{|c|}{ Mean annual genetic gain $\left(\mathrm{kg} \mathrm{ha}^{-1}\right)$} & \multicolumn{2}{|r|}{$42.45 \pm 17.89$} & \\
\hline \multicolumn{2}{|c|}{ Mean annual genetic gain $(\%)$} & \multicolumn{2}{|r|}{$0.7^{*}$} & \\
\hline
\end{tabular}

Table 3. Means of grain yield $\left(\mathrm{kg} \mathrm{ha}^{-1}\right)$ of the groups of introduced and eliminated lines/cultivars and contrast between groups

\begin{tabular}{|c|c|c|c|c|c|}
\hline Years & Introduced lines & $\begin{array}{c}\% \text { in relation to the } \\
\text { control }\end{array}$ & Discarded lines & $\begin{array}{c}\% \text { in relation to the } \\
\text { control }\end{array}$ & Lint-Leli \\
\hline $90 / 91 / 92$ & 5688.3 & 100.15 & - & & \\
\hline $92 / 93$ & 4792.7 & 84.38 & 5740.8 & 101.1 & -948.08 \\
\hline $93 / 94$ & 6300.3 & 110.92 & 5169.0 & 91.0 & 1131.3 \\
\hline $94 / 95$ & 5616.4 & 98.88 & 5766.8 & 101.58 & -153.4 \\
\hline $95 / 96$ & 5629.2 & 99.12 & 5377.3 & 94.7 & 251.9 \\
\hline $96 / 97$ & 5460.2 & 96.13 & 5470.9 & 96.3 & -10.65 \\
\hline $97 / 98$ & 6402.6 & 112.72 & 5598.7 & 98.6 & 803.91 \\
\hline $98 / 99$ & 5987.9 & 105.42 & 5896.9 & 103.8 & 91.0 \\
\hline $99 / 00$ & 5708.4 & 100.5 & 6009.4 & 105.8 & -300.97 \\
\hline $00 / 01$ & 6125.9 & 107.85 & & & \\
\hline
\end{tabular}

Mean yield of the controls: $5680.12 \mathrm{~kg} \mathrm{ha}^{-1}$

which associate a high productive potential, disease resistance and top grain quality.

Table 3 displays the results of the comparisons between the grain yield means of the groups of included and discarded lines/cultivars, percentage in relation to the controls and the contrast between groups. The controls were represented by the cultivars Inca, MG1, MG2, BR IRGA-409, Metica 1, Cica 8, and Embrapa 7 Taim, whose adjusted mean was $5680.12 \mathrm{~kg} \mathrm{ha}^{-1}$. In the comparison of the means of the included lines/cultivars with the control means one observes that in the years 1992/93, 1994/95, $1995 / 96$, and 1996/97 these did not exceed the mean of the controls. In the other years, the controls were outmatched by the introduced lines/cultivars, especially by the introductions of 1993/94 and 1997/98. Lines with an unsatisfactory performance are discarded in the evaluation process. Note that in the present study the discarding of lines/cultivars was effective in some years, since the means of this group of lines were lower than the control mean. This is reinforced by the contrast between the group of lines/cultivars included and discarded, where the values were high and significant in 1993/94 and 1997/98, indicating the superiority of the introduced lines/cultivars. Negative and significant contrasts indicate that the discarded lines/ cultivars performed better than the included, result observed in 1992/93. The lines/cultivars introduced in this year presented low means and were discarded in the following year, especially line CNA 7552, which was the 
least produtive in relation to all evaluated genotypes in these 11 years (Table 1 ).

The contrasts between the means of the controls, means of the released cultivars and means of the elite lines are represented in Table 4. The controls are represented by the oldest rice cultivars within the group of the commercial cultivars. The elite lines are those that presented the highest means in this study and will be further evaluated in the program. The only significant contrast was observed between the mean of the controls and the elite lines, indicating that the improvement program presents a potential for the release of cultivars that outmatch the controls, mainly the lines CNA 8879, CNA 8575, PR 501, CNA 8731, CNA 8479, which were evaluated in 2001/2002. The contrast between released cultivars and elite lines shows that the gain in yield was low. The mean of the elite lines did not outrival the cultivars released in the 90s, reinforcing results of another study (Santos et al. 1999). In this case it is important that the breeder establishes new improvement strategies to explore the existing genetic potential in irrigated rice, aiming at the establishment of cultivars that are not only diseaseresistant and of good grain quality, but that are also more productive. Along with these strategies the number of trials

Table 4. Contrasts between means of grain yield $\left(\mathrm{kg} \mathrm{ha}^{-1}\right)$ of groups of controls, released cultivars and elite lines

\begin{tabular}{lccc}
\hline Groups & Means & Released cultivars & Elite lines \\
\hline Controls $^{1}$ & 5680 & -324 & $-1004 *$ \\
Released cultivars & 6004 & -680 \\
Elite lines & & \\
\hline & 6684 & \\
'Inca, MG1, MG2, BR-IRGA-409, Metica 1, Cica8, Embrapa 7 Taim \\
'2Capivari, Urucuia, Sapucaí, Aliança, Rio Formoso, Rio Grande, Ouro Minas, \\
Jequitibá and Mucuri \\
'SC 141, CNA 8879, CNA 8575, PR 501, CNA 8731, PR 498, and CNA 8479 \\
*Significant at 5\% probability by the Tukey test
\end{tabular}

in the state of Minas Gerais should be increased, considering the importance of the crop and the increasing difficulty of detecting differences between lines. This fact is aggravated by the low number of number of lines that are evaluated by the program (105 in 10 years), compared with other crops. Based on the program of cooperation with the Embrapa Arroz and Feijão in the development of lines, the number of evaluated lines can be increased, making the program more dynamic with the possibility of increasing the gains.

A summary of the dynamics of the improvement program in 11 years is presented in Table 5. The rate of inclusion measures the number of new lines/cultivars created by the improvement program in relation to the previous year. This value was greater between 93/94 and $94 / 95(58.62 \%)$, expressed in the gain obtained in this phase (Table 2), which can also be proved by the high mean of these introduced lines (Table 3 ).

The percentage of renovation expresses the rate of new lines/cultivars among those that are being tested in a particular year and again, the quantity of lines/cultivars renewed in 93/94 and 94/95 was high and important for the headway of the improvement program. This decade was a period of transition in improvement; in the beginning the renovation of lines was low, became significant in 1993/94 and remained intermediate until 1999/00 and 2000/01.

\section{CONCLUSIONS}

The genetic improvement program of irrigated rice of Minas Gerais in the 90s was effective (genetic gain of $0.7 \%$ per year for grain yield) in the development of lines and the release of cultivars.

Table 5. Percentage of inclusion and exclusion; maintenance and renovation/renewal and of lines throughout the 11 years of the genetic improvement program of irrigated rice in Minas Gerais

\begin{tabular}{lcccc}
\hline Years & Inclusion $(\%)$ & Exclusion $(\%)$ & Maintenance $(\%)$ & Renewal $(\%)$ \\
\hline $92 / 93-90 / 91 / 92$ & 13.04 & 30.43 & 56.52 & 18.75 \\
$93 / 94-92 / 93$ & 11.11 & 33.33 & 55.56 & 16.67 \\
$94 / 95-93 / 94$ & 58.62 & 17.24 & 24.14 & 70.83 \\
$95 / 96-94 / 95$ & 22.58 & 22.58 & 54.84 & 29.17 \\
$96 / 97-95 / 96$ & 29.41 & 26.47 & 44.12 & 40.00 \\
$97 / 98-96 / 97$ & 24.24 & 24.24 & 51.52 & 32.00 \\
$98 / 99-97 / 98$ & 32.43 & 29.73 & 37.84 & 46.15 \\
$99 / 00-98 / 99$ & 35.00 & 40.00 & 25.00 & 58.33 \\
$00 / 01-99 / 00$ & 29.41 & 38.24 & 32.35 & 47.62 \\
\hline
\end{tabular}




\title{
Ganho genético do programa de melhoramento de arroz irrigado de Minas Gerais
}

\begin{abstract}
RESUMO - Visando avaliar o programa de melhoramento genético de arroz irrigado de Minas Gerais estimou-se o ganho genético obtido na década de 90. Utilizaram-se dados de produtividade de grãos dos ensaios comparativos avançados de cultivares e linhagens de arroz irrigado por inundação contínua, conduzidos no período de 1990/91 a 2000/01. Para obtenção da estimativa do ganho genético, foi usada a metodologia das médias ajustadas proposta por Breseghello (1998). O ganho genético médio anual na década de 90 foi de 42,45 $\pm 17,89 \mathrm{~kg} \mathrm{ha}^{-1}$ (0,7\%* ao ano). O programa de melhoramento mostrou-se promissor para o desenvolvimento de linhagens que superem as testemunhas, porém, a média das cultivares lançadas na década de 90 não superou a média das linhagens elites, que são materiais que apresentaram as maiores médias neste trabalho e continuarão sendo avaliadas pelo programa.
\end{abstract}

Palavras-chave: Oryza sativa, melhoramento genético, cultivares.

\section{REFERENCES}

Abreu AFB, Ramalho MAP, Santos JB and Martins LA (1994) Progresso genético do melhoramento genético do feijoeiro nas décadas de setenta e oitenta nas regiões Sul e Alto Paranaíba em Minas Gerais. Pesquisa Agropecuária Brasileira 29: 105-112

Breseghello F, Morais OP and Rangel PHN (1998) A new method to estimate genetic gain in annual crops. Genetic and Molecular Biology 21: 551-555.

Breseghello F, Rangel PHN and Morais OP (1999) Ganho de produtividade pelo melhoramento genético do arroz. Pesquisa Agropecuária Brasileira 34: 399-407.

Carvalho LP, Barbisa MHP, Costa JN, Farias FJCF, Santana JCF and Andrade FP (1997) Progresso genético do algodoeiro herbáceo do Northeast. Pesquisa Agropecuária Brasileira 32: 283-291.

Cruz CD (2001) Programa Genes - Versão Windows: aplicativo computacional em genética e estatística. Editora UFV, Viçosa, 648p.

Fernandes JSC and Franzon JF (1997) Thirty years of genetic progress in maize (Zea mays L.) in a tropical environment. Maydica 42: 21-27.
Machado JRA, Santos PG, Penna JCV, Falieri J and Lanza MA (2003) Progresso genético do programa de melhoramento do algodoeiro herbáceo em Minas Gerais. In: Anais do II Congresso Brasileiro de Melhoramento de Plantas. Sociedade Brasileira de Melhoramento de Plantas, Porto Seguro, (CD-ROM).

Rangel PHN, Pereira JA, Morais OP, Guimarães EP and Yokokura $T$ (2000) Ganhos na produtividade de grãos pelo melhoramento genético do arroz irrigado no meio-norte do Brasil. Pesquisa Agropecuária Brasileira 35: 1595-1604.

Santos PG, Soares P, Soares AA, Morais OP and Cornélio VMO (1999) Avaliação do progresso genético obtido em 22 anos no melhoramento do arroz irrigado em Minas Gerais. Pesquisa Agropecuária Brasileira 34: 1889-1896.

Soares AA and Ramalho MAP (1993) Estimativas do progresso genético no melhoramento do arroz (Oryza sativa L.): I Comparação de métodos. Ciência e Prática 17: 27-34.

SAS Institute Inc. (1985). SAS user's guide: statistics, Version 5 ed. SAS Institure, Cary, 956p.

Vencovsky R, Moraes AR, Garcia JC and Teixeira NM (1986) Progresso genético em vinte anos de melhoramento de milho no Brasil. In: XVI Congresso Nacional de Milho e Sorgo. Associação Brasileira de Milho e Sorgo, Sete Lagoas, p. 300307 . 